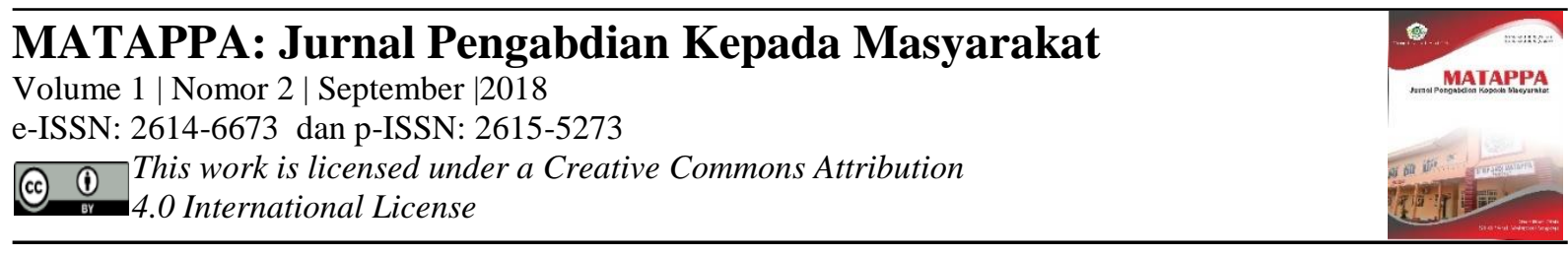

\title{
Pelatihan Penelitian Tindakan Kelas (PTK) Sebagai Upaya Meningkatkan Motivasi Kelompok Guru Kecamatan Bua Meneliti
}

\author{
Bobby Poerwanto ${ }^{1}$, Baso Ali $^{2}$
}

\author{
Keywords : \\ PTK; \\ Penelitian Guru; \\ Pendidikan

\section{Corespondensi Author} \\ ${ }^{1}$ Statistika, Universitas \\ Cokroaminoto Palopo \\ BTN Nyiur 19 No 17, Palopo \\ Email: bobbybp89@gmail.com
}

\section{History Artikel}

Received: 10-06-2018

Reviewed: 21-06-2018

Revised: 05-07-2018

Accepted: 09-07-2018

Published: 27-07-2018

\begin{abstract}
Abstrak. Kegiatan ini bertujuan untuk membiasakan guruguru untuk melakukan penelitian tindakan kelas, sehingga masalah-masalah yang terjadi di kelas bisa diselesaikan dengan penelitian. Subjek kegiatan ini adalah guru dari SMPN 2 Bua dan SMPN Satap Raja Bua. Kedua sekolah ini dipilih karena di Kecamatan Bua, sekolah ini yang masih berakreditasi B. Materi kegiatan ini ada 3 yaitu kebijakan pemerintah tentang penelitian, teknis pelaksanaan PTK, dan model pembelajaran inovatif. Hasil dari kegiatan ini adalah dari 31 peserta, dan semua peserta ingin melakukan PTK setelah kegiatan ini. Kebanyakan dari para guru belum melakukan PTK karena tidak mengetahui teknis pelaksaan PTK.
\end{abstract}

\begin{abstract}
This activity aims to familiarize teachers for conducting classroom action research, so that problems that occur in the classroom can be solved by research. The subjects of this activity are teachers from SMPN 2 Bua and SMPN Satap Raja Bua. Both schools are selected because they are still accredited $B$. The material of this activity there are 3, namely government policies on research, technical implementation of PTK, and innovative learning model. The result of this activity is from 31 participants, and all of them want to conduct PTK. Most of the teachers haven't done the PTK because they don't know the technical implementation of PTK
\end{abstract}

\section{PENDAHULUAN}

Pendidikan adalah salah satu indikator kunci kemajuan suatu bangsa. Masyarakat Indonesia dengan laju pembangunannya masih menghadapi masalah pendidikan yang berat, khususnya bagaimana menyelenggarakan pendidikan yang tanggap dalam menghadapi tantangan era globalisasi. Dalam menyongsong era globalisasi tersebut, bangsa Indonesia dituntut untuk berkompetisi dengan bangsa- bangsa lain di dunia dalam menguasai ilmu pengetahuan dan teknologi sehigga masalah pendidikan merupakan salah satu prioritas utama yang harus dipacu dalam menopang pembangunan suatu bangsa..

Ada dua komponen penting dalam berlangsungnya pendidikan yaitu pengajar dan peserta didik. Untuk terus memperbaiki hasil dan motivasi belajar, pengajar diharapkan mampu melakukan penelitian tindakan kelas (PTK). Kewajiban penelitian diberlakukan 
kepada guru golongan III.b. ke atas. Pemberlakuan PTK mengacu pada Peraturan Menteri PAN No. 16 tahun 2009 pasal $11 \mathrm{C}$ yang menyebutkan bahwa Pengembangan keprofesian berkelanjutan, meliputi: 1 . pengembangan diri: a) diklat fungsional; dan b) kegiatan kolektif guru yang meningkatkan kompetensi dan/atau keprofesian guru; 2. publikasi Ilmiah: a) publikasi ilmiah atas hasil penelitian atau gagasan inovatif pada bidang pendidikan formal; dan b) publikasi buku teks pelajaran, buku pengayaan, dan pedoman guru; 3. karya Inovatif: a) menemukan teknologi tepat guna; b) menemukan/menciptakan karya seni; c) membuat / memodifikasi alat pelajaran /peraga /praktikum; dan d) mengikuti pengembangan penyusunan standar, pedoman, soal dan sejenisnya.

Kewajiban guru untuk melakukan PTK diharapkan mampu untuk terus menerus mengembangkan kualitas pendidikan di Indonesia yang menurut Prima Roza (2007) masih memprihatinkan. Keaktifan guru dalam melakukan penelitian juga akan mempengaruhi akreditasi sekolah berdasarkan standar IV tentang pendidik dan tenaga kependidikan. Berdasarkan data yang diperoleh dari Kemendikbud (2017), diperoleh jumlah sekolah per jenjang per akreditasi sebagai berikut (Kemdikbud, 2017)

\begin{tabular}{|c|c|c|c|}
\hline Jenjang & SD & SMP & SMA \\
\hline Negeri Akreditasi A & $48,401 \quad(7.62 \%)$ & $35,876 \quad(7.79 \%)$ & $38,401 \quad(7.9 \%)$ \\
\hline Negeri Akreditasi B & $109,917(17.3 \%)$ & $76,700 \quad(16.64 \%)$ & $78,763 \quad(16.2 \%)$ \\
\hline Negeri Akreditasi C & 29,508 (4.64\%) & $21,438 \quad(4.65 \%)$ & $22,072 \quad(4.54 \%)$ \\
\hline Swasta Akreditasi A & $17,058 \quad(2.68 \%)$ & $13,539 \quad(2.94 \%)$ & $15,444 \quad(3.18 \%)$ \\
\hline Swasta Akreditasi B & $23,940 \quad(3.77 \%)$ & $19,264 \quad(4.18 \%)$ & $22,238 \quad(4.57 \%)$ \\
\hline Swasta Akreditasi C & $7,494 \quad(1.18 \%)$ & $(1.28 \%)$ & $(1.4 \%)$ \\
\hline Belum Akreditasi & $399,071(62.81 \%)$ & $288,114(62.52 \%)$ & $302,533(62.22 \%)$ \\
\hline
\end{tabular}

Sumber : data.go.id (olahan)

Pada tabel 1 terlihat bahwa sekolah dengan akreditasi B yang masih banyak di Indonesia, swasta dan negeri dan untuk setiap jenjang. Oleh karena itu, kegiatan pelatihan dan pendampingan penelitian tindakan kelas sebagai upaya untuk meningkatkan standar kompetensi pendidik akan dilakukan pada guru-guru jenjang SMP. Kegiatan ini akan dilaksanakan di kecamatan Bua Kabupaten Luwu, hal ini didasarkan pada data di kecamatan tersebut ada dua SMP yang masih berakreditas B yaitu SMPN 2 Bua dan SMPN 1 Atap Raja (Kemdikbud, 2016). Kedua sekolah tersebut berada cukup jauh dari kampus-kampus pendidikan, kampus pendidikan yang terdekat dari keduanya adalah Universitas Cokroaminoto Palopo yang mempunyai fakultas ilmu pendidikan dan berjarak kurang lebih $15 \mathrm{~km}$. Sehingga dalam melaksanakan Peraturan Menteri PAN No. 16 tahun 2009 pasal 11 C, diharapkan kontribusi dari perguruan tinggi

\section{METODE}

Berdasarkan permasalahan yang telah dibahas di pendahuluan, solusi yang ditawarkan adalah pelatihan dalam melakukan PTK. Selain untuk dapat digunakan sebagai syarat kenaikan pangkat, melakukan PTK juga telah terbukti sebagai bahan evaluasi guru dalam mengajar seperti yang dikemukakan oleh Poerwanto
(2016), Maisaroh dan Rostrieningsih (2010) dan Widodo dan Widayanti (2013). Apakah selama ini metode mengajar dan media ajar telah benarbenar dapat meningkatkan hasil belajar dan kegiatan positif di kelas atau tidak, sehingga ke depannya terdapat proses refleksi yang dapat dijadikan acuan untuk terus membenahi diri dalam mempersiapkan pengajaran. Mitra dalam kegiatan ini adalah SMPN 2 Bua dan SMPN Satap Raja Bua. pelaksanaan kegiatan ini adalah sebagai berikut:

1. Tahap Persiapan

Langkah-langkah dalam tahap ini adalah studi literatur, pembuatan handout dan bahan Adapun detail langkah tersebut adalah sebagai berikut:

a. Melakukan studi literatur tentang pengantar PTK, jumlah siklus yang baik dalam PTK, dan indikator keberhasilan penelitian

b. Membuat handout dan bahan presentasi untuk guru sebagai bahan acuan dalam melakukan PTK, materi ini diberikan dan dipresentasikan pada saat pelatihan berlangsung.

c. Membuat angket kepuasan dengan tujuan untuk mengukur respon peserta pelatihan dalam kegiatan ini, apakah kegiatan ini sudah sesuai dengan kebutuhan mereka atau tidak. Adapun item yag diukur adalah tingkat
Uraian umum tentang tahapan presentasi serta pembuatan angket kepuasan. 
kepuasan peserta dari segi fasilitas ruangan, materi yang disampaikan, cepat tanggap panitia, besar pengaruh pelatihan terhadap keinginan melakukan PTK, apakah peserta pernah melakukan PTK dan alasannya.

2. Tahap Pelaksanaan

Pada kegiatan ini guru dipersiapkan untuk melakukan PTK dengan terlebih dahulu diberikan materi tentang kebijakan pemeritah tentang penelitian gutu, teknis pelaksanaan PTK, dan model pembelajaran inovatif.

3. Tahap Pelaporan

Setelah guru melakukan semua kegiatan PTK, mereka akan diminta mengisi angket kepuasan untuk mengukur apakah pelatihan dan pendampingan ini efektif atau tidak. Langkah terakhir dalam tahap ini adalah pembuatan laporan serta mempersiapkan luaran yang dijanjikan.

Program rencana keberlanjutan melibatkan kedua mitra untuk terus mengembangkan dan berinovasi dalam melakukan penelitian tindakan kelas. Selain itu, hal utama dalam keberlanjutan program ini adalah adanya publikasi ilmiah yang dilakukan oleh guru-guru dari SMPN 2 Bua dan SMPN Satap Raja. Universitas Cokroaminoto Palopo akan membantu dalam hal konsultasi pembuatan artikel ilmiah yang siap dipublikasikan dalam jurnal dan juga seminar nasional, serta menyediakan jurnal untuk media publikasi ilmiah guru-guru peserta pelatihan PTK

\section{HASIL DAN PEMBAHASAN}

\section{a. Permasalahan Mitra}

Berdasarkan hasil observasi, terdapat dua masalah utama mengapa SMPN 2 Bua dan SMPN 1 Atap Raja masih belum bisa melaksanakan secara maksimal kewajiban melakukan penelitian tindakan kelas. Yang pertama adalah guru-gurunya masih sangat jarang melakukan penelitian dikarenakan mereka fokus ke mendidik, mengajar, membimbing, mengarahkan, melatih, menilai, dan mengevaluasi peserta didik pada pendidikan anak usia dini jalur pendidikan formal sebagai tugas utama mereka dalam dalam Undangundang No.14 tahun 2005 tentang guru dan

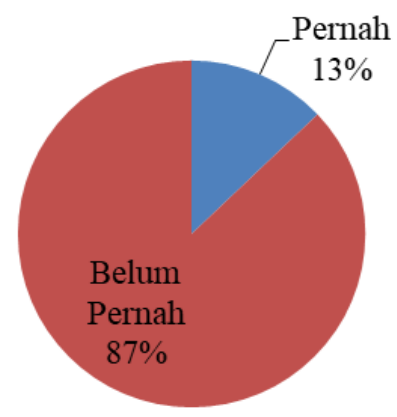

dosen pada Pasal 1 ayat 1 .

Permasalah kedua adalah pengetahuan mereka dalam melakukan penelitian tindakan kelas masih sangat minim. Lebih jelasnya dapat dilihat pada gambar 1 di bawah

Gambar 1: Persentase peserta yang telah melakukan PTK

Dengan jumlah peserta 31 orang, terlihat pada Gambar 1 bahwa jumlah guru yang belum pernah melakukan PTK masih sangat banyak, sekitar 27 orang (87\%), dan hanya sekitar 4 orang (13\%) yang pernah melakukan PTK.

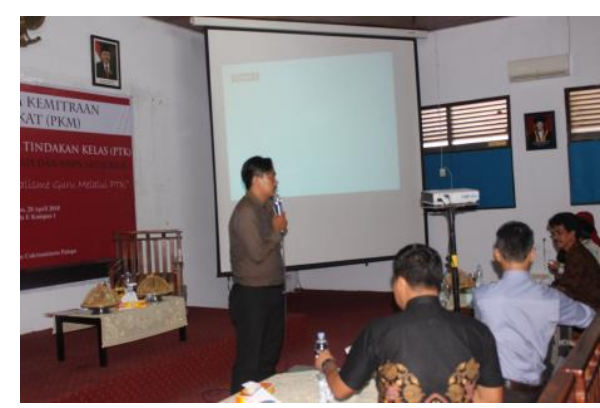

Gambar 2: Tim Memberikan Materi dalam Seminar PTK

Lebih lanjut, Gambar 3 memberikan gambaran pengalaman guru-guru tersebut melakukan penelitian semenjak jadi guru 


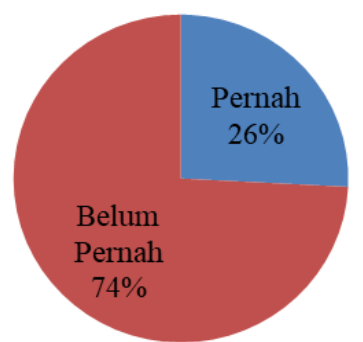

Gambar 3: Persentase peserta yang pernah melakukan penelitian

Berdasarkan gambar 3 di atas terlihat bahwa semenjak jadi guru hanya ada sekitar 8 orang (26\%) yang pernah melakukan penelitian, sisanya belum pernah melakukan.

Selanjutnya akan dilihat hasil kegiatan dalam bentuk respon para peserta terkait hal-hal yang diukur yang telah dijelaskan pada bagian metodologi.

\section{Fasilitas Ruangan}

Respon peserta untuk kategori fasilitas ruangan dapat dilihat pada gambar 4 di bawah

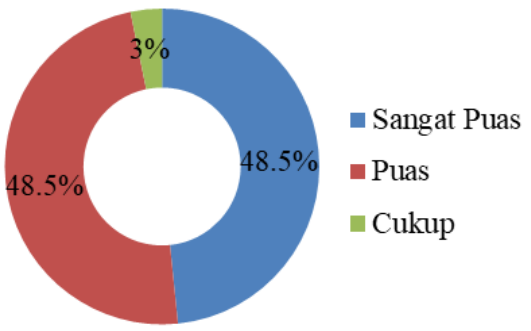

Gambar 4: Persentase respon peserta terhadap fasilitas ruangan

Pada gambar 4 terlihat bahwa secara umum para peserta puas dengan fasilitas ruangan yang diberikan. Adapun fasilitas yang diberikan adalah LCD, screen, AC.

\section{Materi yang Disampaikan}

Pada kegiatan ini ada 3 materi yang diberikan, yaitu teknis pelaksanaan PTK oleh Dr. Ma'rufi, M.Pd dan Bobby Poerwanto, S.Pd., M.Si. Materi kedua adalah tentang kebijakan pemerintah dalam hal penelitian guru yang dibawakan oleh Prof. Dr. Syafruddin Side, S.Si., M.Si.

Dan, materi yang terakhir adalah model pembelajaran inovatif yang dibawakan oleh Baso Ali, S.Pd., M.Pd. Adapun tanggapan peserta diberikan pada gambar 5 di bawah

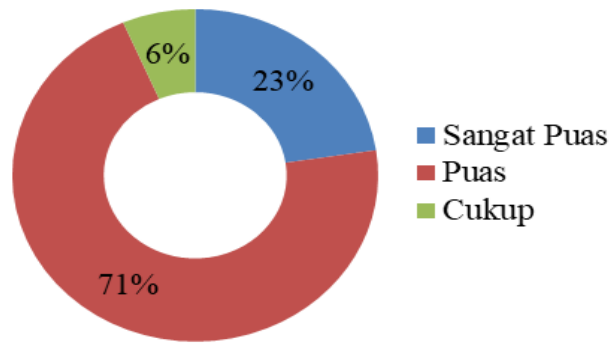

Gambar 5: Persentase respon peserta terhadap materi yang diberikan

Secara umum, tidak ada peserta yang merasa tidak puas dengan materi yang diberikan. Terlihat pada gambar bahwa sebesar $71 \%$ peserta merasa puas, dan $23 \%$ merasa sangat puas. Pada gambar, hanya terdapat $6 \%$ peserta yang merasa cukup.

\section{Dampak Seminar PTK}

Ukuran yang digunakan untuk melihat dampak pelaksanaan seminar PTK ini adalah respon peserta tentang apakah mereka ingin melakukan PTK setelah seminar ini. Untuk lebih jelasnya, dapat dilihat pada gambar 6 di bawah

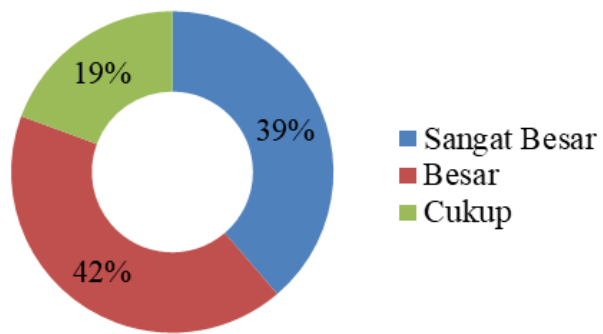

Gambar 6: Persentase respon peserta terhadap dampak seminar PTK

Berdasarkan gambar 6 di atas terlihat bahwa mayoritas peserta merasa termotivasi melakukan PTK setelah seminar ini. Hanya sekitar 19\% yang merasa cukup, dan tidak ada peserta yang merasa kegiatan ini tidak berdampak apa-apa terhadap keinginan melakukan PTK.

Lebih lanjut, gambar 7 di bawah menjelaskan tentang berapa persen peserta yang ingin melakukan PTK setelah seminar ini

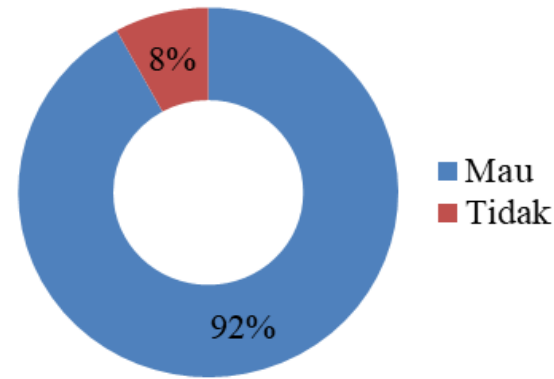

Gambar 7: Persentase respon peserta keinginan melakukan PTK

Dari 25 guru yang menjawab pertanyaan ini, 
sebesar 92\% ingin melakukan PTK, dan sisanya menjawab tidak.

Secara umum, kedua mitra dalam kegiatan ini adalah sekolah yang masih sangat minim dalam hal pengalaman meneliti. Hal ini dapat dilihat pada gambar 1 dan gambar 3. Terdapat 87\% peserta belum pernah melakukan PTK dan sama sekali belum pernah melakukan penelitian apapun $74 \%$. Penyebabnya adalah sebagian besar (54\%) di antara mereka tidak mengetahui cara melakukan PTK, dan sebesar $10 \%$ mengatakan bahwa mereka tidak mempunyai waktu yang banyak untuk melakukan PTK.

Berdasarkan hal tersebut, maka bobot waktu materi pertama tentang teknis pelaksanaan PTK lebih banyak dibandingkan yang lain.

Pada penyampaian materi pertama, selain penjelasan tentang PTK itu senditi, Dr. Ma'rufi, M.Pd dan Bobby Poerwanto, S.Pd., M.Si menjelaskan beberapa poin penting dalam pelaksanaan PTK seperti pentingnya masalahmasalah yang terjadi di kelas sebaiknya dapat diselesaikan oleh guru melalui penelitian, halhal apa saja yang dapat ditingkatkan selain hasil belajar dalam PTK.

Disamping itu, diberikan juga contoh PTK yang pernah dilakukan sehingga para peserta sudah mendapatkan gambaran tentang persiapan, pelaksanaan, dan pelaporan PTK. Sebagai tambahan, pada materi pertama ini ada juga sesi diskusi judul PTK yang ingin diangkat oleh para peserta. Guru-guru menuangkan masalah yang ditemukan di kelas, lalu kemudian diberikan solusi yang mungkin dapat membantu sehingga pada sesi pertama guru sudah mempunyai judul penelitian untuk dilakukan.

Memasuki sesi kedua, para peserta diberikan pengetahuan tambahan tentang kebijakan Pemerintah dalam hal penelitian guru. Prof. Dr. Syafruddin Side, S.Si., M.Si yang menjadi pemateri pada sesi ini menekankan beberapa hal yaitu para guru harus membiasakan diri untuk melakukan penelitian. Disamping untuk kenaikan pangkat, penelitian juga merupakan indikator keprofesionalan guru dalam mengajar. Selain itu, para peserta juga diberikan materi tentang pentingnya melakukan publikasi. Penelitian yang dilakukan guru bisa dijadikan beberapa luaran seperti publikasi ilmiah, alat peraga, dan bahan ajar.

Materi ketiga tentang model pembelajaran inovatif, adapun model yang difokuskan adalah model yang bersifat student-centre learning). Materi yang dibawakan adalah model PAKEM (Pastisipasi, Aktif, Kreatif, Efektif, dan
Menyenangkan), dan bahan ini dibawaka oleh Baso Ali, S.Pd., M.Pd.

Berdasarkan observasi awal, banyak guru yang mengeluh tentang pembelajaran pada jamjam setelah istirahat dimana kebanyakan siswa sudah mengantuk dan lelah. Sehingga, salah satu alternatif solusi yang ditawarkan adalah model PAKEM. Hal ini bertujuan agar dapat membuat peserta didik menikmati proses belajar sambil bermain.

Dengan materi ini para peserta diharapkan output berupa para guru dapat membuat pembelajaran yang bermutu, memberikan perubahan dalam peran guru di kelas, interaksi kepada peserta didik, membimbing kemampuan bertanya, serta menjadikan pengelolaan kelas dan guru itu sendiri inovatif.

Kegiatan ini cukup berdampak bagi para peserta. Dari keseluruhan peserta hanya 19\% yang merasa dampak kegiatan ini cukup besar, dan sisanya merasa puas dan sebesar $92 \%$ peserta ingin mencoba melakukan PTK setelah kegiatan ini.

\section{SIMPULAN DAN SARAN}

Berdasarkan hasil kegiatan yang telah dilakukan bersama dengan mitra SMPN 2 Bua dan SMPN Satap Raja, maka dapat disimpulkan bahwa seminar pelatihan PTK berpengaruh signifikan terhadap motivasi guru-guru dalam melakukan PTK. Selain itu juga, kegiatan ini dirasa sangat penting mengingat banyak guru yang belum pernah melakukan penelitian karena tidak mengetahui teknis pelaksanaannya.

Adapun saran dalam kegiatan ini adalah sebaiknya untuk kegiatan ke depan dilanjutkan dengan pendampingan melakukan PTK, sehingga guru mempunyai tempat bertanya ketika sedang melakukan PTK, dan berujung pada terjaminnya kegiatan PTK yang dilakukan oleh guru sesuai standar dan tahapan PTK itu sendiri.

\section{UCAPAN TERIMA KASIH}

Ucapan terima kasih yang sebesarbesarnya kami berikan kepada Kemristekdikti yang telah membiayai kegiatan ini melalui skema Program Kemitraan Masyarakat (PKM). Terima kasih pula untuk Prof. Dr. Syafruddin Side, S.Si., M.Si dan Dr. Ma'rufi, M.Pd yang telah meluangkan waktunya menjadi pembicara tamu pada kegiatan ini. 


\section{DAFTAR RUJUKAN}

Kemdikbud, 2016. Pencarian Sekolah. http://sekolah.data.kemdikbud.go.id/index.ph p/chome/ pencarian/. Diakses tanggal 1 Juni 2017.

Kemdikbud, 2017. Sekolah Per Jenjang dan Akreditasi. https://data.go.id/dataset/sekolahper-jenjang-akreditasi. Diakses tanggal 1 Juni 2017

Maisaroh, \& Rostrieningsih. (2010). Peningkatan Hasil Belajar Siswa Dengan Menggunakan Metode Pembelajaran Active Learning Tipe Quiz Team Pada Mata Pelajaran Keterampilan Dasar Komunikasi Di SMK Negeri 1 Bogor - Maisaroh dan Rostrieningsih. Jurnal Ekonomi Dan Pendidikan, 8(1), 157-172.
Poerwanto, Bobby (2015). Meningkatkan Hasil Belajar Matematika Melalui Penggunaan Media Berbasis Teknologi Informasi dan Komunikasi Pada Siswa Kelas VIII6 SMP Negeri 17 Makassar. Jurnal D'Computare. Vol. 6 No.1, Hal. 12-34

Roza, P. (2007). Pendidikan dan Mutu Manusia. Jurnal Sosioteknologi, 6(12), 303-308.

Widodo, \& Widayanti, L. (2013). Problem Based Learning Pada Siswa Kelas VIIA MTS Negeri Donomulyo Kulon Progo Tahun Pelajaran 2012 / 2013. Fisika Indonesia, XVII(49), 32-35 